\title{
3 Relations between immigration and integration policies in postwar Europe
}

\author{
Marcin Gońda, Magdalena Lesińska \\ and Marta Pachocka
}

\section{Introduction}

Analysing the development of immigration policy in postwar Europe, one may hypothesise that the evolution of the destination country's response to the influx of immigrants is a process which starts from a (wide) open-door policy for foreign workers (as a result of dynamic economic development and a high demand for a cheap foreign labour force). Such a policy has been replaced over time with one of increasing limitations and strict control over the inflow and settlement of immigrants. Migration policy, however, is a set of regulations not only covering immigrants' entries and exits but also adapting to cope with the long-term consequences of the settlement of foreigners - i.e. their integration. There are significant connections between immigration and integration policies, yet it requires a long-term perspective to understand the importance of this interplay. Moreover, both entry regulations and integration policies are affected by a whole range of factors (see Chapter 2, this book).

European countries' experiences of immigration and integration and the corresponding policies have been miscellaneous and conditioned by specific historical and socio-economic contexts, different concepts of nationhood and citizenship, geographical location and regional political constellations. In this chapter, the focus will be on those Western European countries that were at the forefront in experiencing immigration processes and developing models of integration which then became points of reference for other countries. The dynamics of the relationship between immigration and integration policies are closely related to the migratory history of individual countries. In receiving countries, the interest of the authorities and public opinion on immigration and integration issues varied in different periods, depending on the intensity of the inflows of newcomers and their characteristics. This chapter will particularly concentrate on Western Europe for several reasons. Firstly, in the postwar period, countries such as Germany, France, the Netherlands and others in the region were the most important destinations for immigrants both from other continents and from Europe. They had to tackle mass inflows of foreigners and became, in a relatively short time, countries of net immigration - Western Europe became a net immigration regime in the 1950s, whereas Northern and Southern Europe did so in the 1970s (see Okólski 2012). 
Although national variations may be found in the composition and number of foreigners, in the stage of their immigration process and in the models of admission policy implemented by each individual state, the governments had to face the challenge and design their political response to the process of these immigrants' settlement - in other words, integration policy. The diversification of the modes of integration policy developed in Western European countries is another reason for focusing on this particular region. The third reason is that migration flows to and within the European continent have traditionally been regulated by nation-states; however, in recent decades, competence in this field has been partially delegated to the European Union (Scholten and Penninx 2016: 92). The strict connection between national and EU levels in terms of the management of migration flows and attempts to implement a common migration regime operating in all memberstates is an extraordinary example of interstate cooperation; there appear to be no other similar examples noted in the world on such a scale.

The aim of this chapter, therefore, is to examine and reflect on relations between immigration (admission) and integration policies, using the example of selected European countries and their grouping (EU). The starting point is that - contrary to traditional thinking - immigration policies are not and should not be considered as superior to and independent from integration policies. Integration policies, particularly their failures, frequently determine immigration policies at a later stage. Thus, both policies appear to be very interdependent. In detail, the issue of the relationship between immigration and integration policies is examined from three perspectives reflected in the following parts of this chapter. The first of these provides a historical analysis of postwar migration, with special attention paid to the reconstruction of developments in each policy as well as the connections between them (if any). Analyses of state responses to migration show that, in general, efforts to facilitate migrants' integration result from actions already undertaken within admissions measures. In other words, integration policy is reactive and subsequent to immigration policy (see the discussion on this issue in Chapters 1 and 2, this book).

The second part of the chapter examines the approaches to integration and the corresponding policies in selected European countries. On the one hand, integration models implemented in Western European countries with the richest immigration histories and, consequently, with the most advanced integration measures on the Old Continent, are discussed. On the other hand, references to countries that are in transition from emigration to immigration countries in Central Europe are also presented (Van Mol and de Valk 2016). To this end, the third part of the chapter explores the European Union's approach to broadly understood migration and immigrant integration and corresponding policies, underlining their legal framework. The EU as an international organisation whose competence in the field of migration is shared with its member-states, is a special case study. Within its integration policy, the EU only supports national efforts and provides incentives both financial and nonfinancial - to states to enable them to take various actions to empower both third-country citizens living legally in the EU and receiving communities. The reconstruction of the development of immigration and integration 
policies in Europe also serves as an introduction to the following part of the book, dedicated to case-studies of particular countries.

\section{The interplay between immigration and integration policies - an overview of postwar developments}

As the history of the twentieth century shows, perceptions of immigration as a threat increased during wars and periods of political instability, economic crisis and high unemployment, which often coincided with mass population movements. The implementation of immigration control and entry regulations has generally been regarded as necessary by state authorities. Immigration flows that took place between the 1950s and the 1970s can be grouped into two main streams: colonial migration regimes (common for former colonial powers such as the UK, France and the Netherlands) and guestworker policies - which were implemented, inter alia, in Germany, Austria, France, Denmark and Sweden (Hansen 2003: 25). The massive human flows gave rise to a number of challenges for Europe's receiving countries which have remained to this day, with the integration of immigrants being the most notable. The postwar era of the early 1970s requires more comprehensive examination here, as a starting point for European countries' policies aimed at controlling and reducing immigration (Hansen 2003; Van Mol and de Valk 2016). Although the concern to restrain newcomer inflows and to manage the integration of those already settled was originally limited to Western European countries - as 'traditional' destination states - new pressures emerging during the 1980s and 1990s made the immigration issue a salient problem also for 'new' immigration countries in Southern Europe and, in later decades, for Central European countries as well (Okólski 2012).

Until then, migration was determined mainly by market forces and migrants were viewed as strictly temporary - necessity for the purposes of the national economies' recovery in the postwar period and to fill sectoral labour shortages caused by the current rapid economic growth. In many Western European countries, employers were free to recruit foreign workers abroad or to employ those who arrived on their own initiative in search of work. It was - following Thomas Hammar's words - a period of laissez-faire, when governments left the regulation of migration flows to companies and labour-market forces (Hammar 1992: 248). Migration policy was based primarily on the rules of entry and work and on the notion of migrant circulation - entry, work and return - on which the guestworker system was based. Immigrants were to stay only on a temporary basis, with no opportunities for permanent settlement, family migration or societal integration. At that time no measures were taken to integrate foreigners. There was a lurking assumption that this labour migration was temporary and that migrants would return to their home countries once their economic role had been completed.

The economic slowdown and oil crisis that took place in the early 1970s became turning points in the history of migration processes in Europe and marked the beginning of a new way of thinking about immigration and integration policies. In 1971, the UK, followed a year later by Germany, France and then other 
countries, announced the end of an active recruitment policy and employment of foreigners. Subsequent governments began to proclaim the slogan 'zero immigration', meaning the closure of borders to stop the influx of new foreign workers and the implementation of stricter regulations of stay and work for already settled migrants.

Whereas the inflow of foreign workers was limited for the next few decades, family members as well as asylum-seekers from Central and Eastern Europe, Africa and Middle Eastern countries continued to arrive using still-available entry channels. After the borders were closed to labour migrants, legal entry was only possible through the asylum path and arrangements for family reunion. Despite the tightening of the immigration law, the number of newcomers increased in the following years: by 13 per cent in the cases of West Germany (1974-1982) and Great Britain (1971-1981) and by 33 per cent in France (1969-1981) (Moch 1992: 184). Moreover, despite losing their jobs during the economic slowdown, foreign workers did not return to their countries of origin, knowing that rearrival would be difficult, if not impossible. The return programmes introduced by governments to encourage foreigners to leave were also unsuccessful. As a result, the policy of 'closed borders' caused the opposite effect to the expected one: inflows did not stop and, moreover, thousands of foreigners decided to stay in their countries of residence, having no reason to return to the much lower standard of living and development in their countries of origin. By the late 1970s, it was clear that supposedly temporary migration had turned into permanent settlement, resulting in the emergence of multicultural and multilingual societies. The stabilisation of immigrant populations began, family reunion and refugee status gave way to permanent settlement and Western European governments and societies began to perceive immigrants as more permanent rather than merely a temporary component co-shaping national communities. The profile of immigrant-origin communities changed when, instead of male workers, more women as well as younger and older people arrived, with the increased engagement of key social institutions, particularly the welfare state. After all, the governments acknowledged that settled migration meant new challenges in terms of integrating into host societies.

This process caused de facto new policies to emerge. There had been surprisingly little recognition of the potential social and political impacts of immigration and nothing in the way of long-term planning for the integration of immigrants. Traditional assimilation channels were projected in the interwar period for those few who had decided to stay and settle. Since these policies were intended for relatively small groups originating from culturally similar areas, they were unlikely to be successful in the case of diversified and large waves of immigrants arriving from other continents (Doomernik 1998). The recognition of immigrants' permanent settlement led Western European governments to gradually develop activities aimed at the greater integration of immigrants. Initially integration policies had been formulated in a reactive way - as policy-makers did not expect migration to be permanent, they responded to specific problems as they arose, rather than through the formulation of comprehensive and far-sighted strategies (Collison 1993: 90). The state's role was limited to control and to limited forms of integration policy 
focused mainly on legal solutions in the field of anti-discrimination legislation and on the socio-economic dimension (education, housing, the welfare state).

The main aim of a state's activities in this area was to prevent the economic marginalisation of immigrants and to better integrate them into the labour market in order to increase their productivity through access to education, language learning and vocational training. The immigrants' integration was perceived as a one-way process (immigrants were expected to adjust to the host society) and as voluntary (as a right, not an obligation) and felt to be concerned mainly with the economic and social spheres of life, rather than the cultural. It was widely believed that integration was an inevitable process: if not the first generation, then the second and subsequent ones would be sufficiently integrated as a natural consequence of the processes of education and socialisation into the host society. Moreover, an argument was pursued that a successful integration policy depended on strict entry control, meaning in practice that the free influx of foreigners was seen as the major obstacle to the establishment of a peaceful relationship between immigrants and the host society (Brochmann 1995: 115). This approach still remains a key argument shaping migration policies in many countries: integration measures aligned with reinforced attempts to limit any further immigrant inflows.

Demands for the improved enforcement of migration regulations and especially for better control of the admission of asylum-seekers have been raised since the 1990s throughout Europe. It was a time of political instability in many European regions. The collapse of the Iron Curtain, the disintegration of the Soviet Union and Yugoslavia, the opening of the borders of Central and Eastern Europe and, later, the Balkan Wars all induced new migration flows across the Old Continent. Asylum-seekers and refugees joined the guestworkers and family members arriving primarily in the Northwestern European countries. These flows and their consequences created the impetus for an integrated European approach that became part of the 1992 Maastricht Treaty and 1997 Amsterdam Treaty, in which migration and asylum were formally defined as a common policy concern. An overview of several periods in the history of postwar migration processes and policies in Western Europe is presented in Table 3.1.

\section{The variety of integration models in Western European countries}

As evidenced in the previous section and Table 3.1, despite the changing dynamics between immigration and integration policies in postwar Europe, the integration of migrants remains a subsequent and secondary component of migration policy, which explains the certain delay in implementing solutions within admissions policies. Since the integration of migrants is a rising concern not only of individual European countries but also of its supranational representation (EU), in this part we focus on the reconstruction of particular states' responses to this challenge. Making a comparison of policy approaches in this domain is difficult as they are shaped not only by different historical and structural (social, economic and political) or institutional settings but also by dissimilar ideological and 
Table 3.1 Periods in postwar migration processes and policies in Western Europe

\begin{tabular}{|c|c|c|c|}
\hline Period & Main Characteristics & $\begin{array}{l}\text { Immigration } \\
\text { (Admissions) Policies }\end{array}$ & Integration Policies \\
\hline 1945-1971 & $\begin{array}{l}\text { Migration inflows } \\
\text { related to labour } \\
\text { recruitment and } \\
\text { bilateral agreements } \\
\text { resulting from } \\
\text { labour shortages }\end{array}$ & $\begin{array}{l}\text { Policy of open borders } \\
\text { and active recruitment } \\
\text { of foreign workers, } \\
\text { guestworker system }\end{array}$ & - \\
\hline 1971-1973 & 'Immigration stop' & $\begin{array}{l}\text { The end of an active } \\
\text { recruitment policy } \\
\text { and the employment } \\
\text { of foreigners }\end{array}$ & - \\
\hline $\begin{array}{l}\text { 1973-early } \\
\text { 1990s }\end{array}$ & $\begin{array}{l}\text { Inflows due to family } \\
\text { reunion and asylum- } \\
\text { seeking, limited } \\
\text { admission of } \\
\text { guestworkers }\end{array}$ & $\begin{array}{l}\text { Tightening of political } \\
\text { measures: visa } \\
\text { policies, the selective } \\
\text { admission of low- and } \\
\text { high-skilled migrant } \\
\text { workers, restrictions } \\
\text { in family reunion } \\
\text { and asylum schemes; } \\
\text { differentiated national } \\
\text { legislations related to } \\
\text { 'channels of entry' }\end{array}$ & $\begin{array}{l}\text { Introducing voluntary } \\
\text { individual } \\
\text { integration } \\
\text { programmes by } \\
\text { state governments; } \\
\text { tolerance of } \\
\text { diversity; } \\
\text { multiculturalism } \\
\text { as mainstream } \\
\text { approach }\end{array}$ \\
\hline $\begin{array}{l}\text { Late } 1990 \mathrm{~s}- \\
\text { the present }\end{array}$ & $\begin{array}{l}\text { Increasing intra-EU } \\
\text { mobility and } \\
\text { inflows of third- } \\
\text { country nationals; } \\
\text { growing diversity } \\
\text { of immigrant } \\
\text { communities }\end{array}$ & $\begin{array}{l}\text { Building of integrated } \\
\text { European migration } \\
\text { space: common visa } \\
\text { and asylum policy, } \\
\text { freedom of movement } \\
\text { in the EU; policy of } \\
\text { control of external } \\
\text { borders }\end{array}$ & $\begin{array}{l}\text { Shift from voluntary } \\
\text { integration } \\
\text { programmes } \\
\text { towards more } \\
\text { assimilative } \\
\text { approach; } \\
\text { introducing } \\
\text { obligatory } \\
\text { integration courses; } \\
\text { integration as a } \\
\text { condition for third- } \\
\text { country nationals } \\
\text { to enter and stay } \\
\text { in an EU country; } \\
\text { EU initiatives in } \\
\text { integration area }\end{array}$ \\
\hline
\end{tabular}

Source: Authors' elaboration

political understandings of national identity, national cohesion and social order (Rudiger and Spencer 2003; Scholten and Penninx 2016; cf. Favell 2001; Mahning and Wimmer 2000; Penninx 2007). Some are empirically grounded and refer to particular examples of European countries; other are ideal types based on general assumptions and so are not used consistently in any country. They are not stable and permanent but, on the contrary, constitute dynamic and flexible systems 
of principles that undergo some (even fundamental) transformations depending on the macro-structural circumstances. Public attitudes towards immigrants and concepts of integration are continually changing under the influence of a transforming social reality, new political and socio-economic priorities and unexpected events - e.g. the 2015 refugee crisis (cf. Favell 2001; Penninx 2007). Despite these limitations, in the migration literature there are conceptualisations and categorisations of integration policies in Europe that help to clarify that domain.

A good starting point is a well-known study by Rogers Brubaker (1992) on concepts of citizenship and nationhood in France and Germany. He argues that, among others, the postwar immigration and integration practices of these two countries have their roots deep in contradictory ways of nation-state formation, with the French ius soli (granted on the basis of territory or place of birth) and German ius sanguinis (ascribed to the children of citizens) as principles for obtaining citizenship. Two different nation-building processes are reflected in more universal and assimilationist approaches to migrant integration in France and more particularistic and exclusive ones in Germany (Scholten and Penninx 2016).

The deconstruction of different historical patterns of nation-state formation also led Stephen Castles (1995) to propose a typology of policy models concerned with immigration and ethnic diversity. He refers to the degree of acceptance of minority group cultures and distinguishes the differential exclusion model, the assimilation model and the pluralist model. Following the same path, Steven Weldon (2006) proposed a typology of citizenship regimes (i.e. the ways in which citizenship is granted and, thus, determines immigrant integration) that corresponds to the actual immigration policies of European countries (Niekielska-Sekuła 2016). He differentiates between, respectively, collectivistic-ethnic, collectivistic-civic and individualistic-civic regimes (Weldon 2006). Similar categorisation has been elaborated by Rinus Penninx (2007) who provides empirical examples of two basic models of integration policy: exclusionary policy and two variants of inclusion policy - the French (Republican) model and the Anglo-American model. The latter two policies are responses to two different visions of state - citizen relations and, in consequence, the position and role of immigrants in the host societies.

First, within the models oriented towards the exclusion of specific migrant groups (Castles' differential exclusion model, Weldon's collectivistic-ethnic regime and Penninx's exclusionary policy), citizenship is equivalent to ethnicity, which means its acquisition is solely based on the ius sanguinis rule. The host countries which apply this approach are not defining themselves as immigration countries. Since newcomers are perceived as temporary 'guests', they are prevented from permanent settlement (Castles 1995; Weldon 2006). Penninx notes that, since a migrant is defined as an 'alien' and an 'outsider', this approach can, following Alexander's (2007) concepts, be described as a non-policy or a guestworker policy. Migrants are included only in one sphere - usually the labour market but are excluded from civic and political participation and lack a secure legal status. Consequently, it is assumed that there is no need for a complex integration policy that would include the newcomers as full citizens or political actors. Policy instruments are usually accidental and based on ad hoc responses to emerging 
problems. They can be implemented to make immigrants' stay potentially comfortable and profitable for both immigrants and the host country, but the expected result is that the aliens will return to their countries of origin sooner or later (Pen$\operatorname{ninx} 2007)$.

The model was being implemented in Germany, Austria, Denmark, Italy and Greece almost up until the end of the twentieth century (Rudiger and Spencer 2003). In the following decades they withdrew in favour of policies based on a combination of the ius sanguinis and ius soli principles (cf. Favell 2001; Süssmuth and Weidenfeld 2005). Interestingly, elements of this policy can be observed nowadays in Poland (Gońda and Klaus 2018). Castles (1995) argues, however, that this model is difficult to maintain as it may lead to social tensions, and it contradicts the democratic rule of including all members of civil society in a nation-state. Other scholars underline the fact that it restrains integration by leaving migrants in a situation of legal uncertainty, which may lead to a lack of identification with the receiving country's social order and, in turn, increase the host society's xenophobic attitude towards the newcomers (Doomernik 1998).

Second, the assimilationist model is based on the idea of loyalty towards the nation-state. An immigrant is seen as a full member of the host society and is incorporated into the host society through naturalisation. It is expected that immigrants will seek citizenship and, referring to the main political principle of equality, will become fully fledged participants in political life (Penninx 2007). However, given that ethnic roots are not a precondition for attaining citizenship, immigrants of various backgrounds are expected to resign from their cultural distinctiveness. Expressing one's culture of origin is possible only in the private sphere. In order to facilitate the assimilation process, the host country applies different cultural incorporation instruments, e.g. an obligatory official language or education for immigrant children (Castles 1995; Weldon 2006).

This model is commonly associated with the republican tradition of France, which does not officially recognise ethnic minorities as groups with distinct rights. Consequently, there are no relevant policy differences between individuals once they become French citizens. Their national belonging is supposed to be determined by the political order based on substantive values rather than by racial, ethnic or religious background. In this context, the emergence of minorities would lead to a failure of integration (Rudiger and Spencer 2003; cf. Favell 2001). Penninx (2007) also adds that, since immigrant communities are not considered to be separate political actors, the use of notions such as 'ethnicity', 'ethnic minority' or 'multiculturalism' (which may imply collectiveness or institutionalised difference due to origin, culture or religion) is avoided. The issue of immigrants and their integration is then principally depoliticised, which does not mean, however, that they are not present in political debates. This vision, as defined by Penninx, of inclusive policies then has direct implications for integration measures. In the French model, driven by the principle of equality, policies are not targeted at any specific groups (priority is given to general policies) as these would amount to recognising these groups as separate political actors. The result of the implementation of this approach might, however, be counterproductive, as issues with 
mobilising and engaging members of not fully recognised immigrant groups may appear.

The third type of policy model concerns the multicultural approach (as defined by Weldon, an individualistic-civic regime). It is based on a pluralist idea of democracy in which the presence of different ethnic groups is accepted and regulated through a specific management strategy (Rudiger and Spencer 2003). Countries implementing these policies tend to grant ius soli citizenship at birth. Since substantive equality remains a fundamental element of a political system and may, in practice, be related to membership of ethnic or cultural groups, governments should allow for cultural diversity by providing citizens of different backgrounds with the right to manifest their cultural distinctiveness publicly (Weldon 2006). Penninx (2007), in what he calls the Anglo-American inclusive model, underlines that 'ethnicity' or 'multiculturalism' seem relevant terms with which to describe the composition of the host society and, thus, also to become important subjects of political life. Consequently, particular policies are aimed at target groups so that even specific integration instruments (such as positive discrimination or affirmative action) are being used.

This model, however, occurs in various forms, depending on the degree and manner of accepting differences at the institutional level. In practice, the pluralist approach implemented in the UK, the Netherlands and Sweden relies not on the recognition of minority group rights but on a pragmatic management of relations between different ethnicities. This can be achieved not only through enabling different cultural practices but also through anti-discrimination legislation, equal opportunities policies (including access to full civil and political rights) and tailor-made arrangements at the local level to facilitate communication between ethnic groups (Rudiger and Spencer 2003; cf. Bertossi et al. 2015; Favell 2001). Of the three described here, this approach, according to Castles (1995) is the most successful in incorporating immigrants into the host society. Ascribing ethnic and cultural differences in integration processes may lead to a stimulation of the representation of such groups - for example, by extending subsidies directly to immigrant entities. Thus, countries applying the assimilation model have generally moved to a mixed approach, embodying some elements of the pluralist model - which, in consequence, has led to public controversies because of contradictions between explicit goals and actual policies.

To sum up, the typologies mentioned are based on a large body of historical evidence of integration policies developed in different European countries. Their relevance in today's fast-changing realities has, however, been questioned by many scholars. The variety of national models of integration policy has been criticised for over-emphasising the importance of the transnational and local levels, as well as for minimising internal tensions and certain changes over time (Penninx and Garcés-Mascareñas 2016). The optimistic overview of the results of national approaches to integration has also been much present in academic analyses, although there has also recently been some doubt (Scholten and Penninx 2016; cf. Bertossi et al. 2015; Joppke 2007). While the models presented underline national specificities, a closer analysis shows that, as some scholars argue, 
integration and - especially - immigration policies are convergent in practice, proposing parallel solutions for dealing with increasing immigration. This is especially evident at the local level, where problems and their solutions often appear to be similar across Europe. These transnational similarities leave space for a more active role of the EU in facilitating integration, which could help to overcome the limitations created by national policies (Rudiger and Spencer 2003; cf. Mahning and Wimmer 2000).

Many studies show that migrant integration still remains a nation-state's sphere of influence because ideas for the newcomers' integration are much correlated with notions of national identity and belonging. However, several research outcomes suggest that the top-down or centralist model has become much less applicable to the practice of migrant integration policy-making in many European countries. Interestingly, in this domain, we can also observe shifts away from historically grounded state-centric policies towards integration strategies developed and implemented at the local level (cities and local governments). This 'local turn' in migrant integration policies is supposed to better answer to migrants' needs and to effectively help to manage growing ethnic diversity (Scholten and Penninx 2016; cf. Alexander 2007; Caponio and Borkert 2010; Entzinger and Scholten 2014). At the same time, apart from the decentralisation of integration policies and following the terminology applied by Scholten and Penninx (2016), a tendency towards the multilevel governance of migrant integration is observed. State authorities maintain their influence on integration policies (mostly through funding mechanisms) or are even asked by local governments to become more involved. Since the 2007 Treaty of Lisbon, the EU has also left its institutions with the mandate that they should do whatever is required.

\section{Towards a European model of immigration and integration policies?}

With the deepening of European integration processes and the subsequent legal and institutional reforms of the European Communities and the European Union, the place of migration issues and their scope have also changed. The number of member-states has been increasing and, thus, the migration experience and the catalogue of national policies have diversified. Until the late 1990s, the driving force behind European integration was the states of Northwestern and Southern Europe, whose interests shaped the EU approach to migration. Among them were former colonial states dealing with the consequences of the past as well as new immigration countries receiving labour migrants and asylum-seekers. On the contrary, the new member-states that joined the Union in 2004, 2007 and 2013 were the Central and Eastern European countries from the former Eastern Bloc and the USSR, as well as Croatia, once part of the former Yugoslavia, whose experiences with international migration until the 1990s were limited and whose migration policies were thus not developed (see Castles et al. 2014; Doomernik and Bruquetas-Callejo 2016). While the old EU members had a greater impact on the creation of a migration policy towards third-country nationals from outside 
the EU in a bottom-up way, new countries have, instead, been adopting certain solutions based on a top-down logic while preparing for their EU accession and then in the first years of their membership (see Doomernik and Bruquetas-Callejo 2016; Van Wolleghem 2019).

The founding treaties did not yet refer to international migration (that is, to third-country nationals) per se. Until the mid-1980s, the issue of the influx of citizens from third countries was the subject of intergovernmental cooperation which was beyond the competence of the European Communities. In the second half of the 1980s, several working groups were set up as part of the preparations for establishing the internal market. The result of cooperation between member-states at this stage was, among others, the adoption of the Dublin Convention, determining the state responsible for examining applications for asylum lodged in one of the member-states of the European Communities in 1990. The second half of the 1980s was also marked by the cooperation between European countries in order to gradually abolish the checks at their common borders and to create the Schengen Area without internal borders. The Treaty of Maastricht (1992) was crucial for the development of EU policies towards third-country nationals. The legal basis and the institutional framework for cooperation in this area were covered under the third pillar of the EU legal system, encompassing justice and home affairs. The Treaty of Amsterdam (1997) limited the scope of the third pillar to police and judicial cooperation in criminal matters, while issues regarding migration and asylum were transferred to the first pillar, based on the Community integration method with the strongest supranationalism (see Borawska-Kędzierska and Strąk 2011; Duszczyk 2011).

Of the greatest importance for the development of the EU's approach to migration and integration of migrants was the Treaty of Lisbon (2007) $)^{1}$ which gave the European Union a full legal personality. Consequently, nowadays, EU policy in relation to broadly understood migration is part of the area of freedom, security and justice, which is subject to shared competences between the EU and its member-states. This means that both parties can legislate and adopt legally binding acts in this field. Article 3(2) of the TEU stipulates

The Union shall offer its citizens an area of freedom, security and justice without internal frontiers, in which the free movement of persons is ensured in conjunction with appropriate measures with respect to external border controls, asylum, immigration and the prevention and combating of crime.

(European Union 2016a)

Only a few articles (Articles 67, 77-80) under Title V of the Treaty on the Functioning of the EU outline the general legal framework for three specific policies on border checks, asylum and immigration in EU primary law. The scope of the latter covers such matters as

the efficient management of migration flows, fair treatment of thirdcountry nationals residing legally in Member States, and the prevention 
of, and enhanced measures to combat, illegal immigration and trafficking in human beings.

(European Union 2016b: Article 79(1))

In order to make this possible, the Union may reach for specific measures concerning, inter alia, conditions of entry and residence on its territory, the rights of third-country nationals legally living in the EU, the prevention of illegal immigration and residence, the fight against trafficking in human beings and the conclusion of readmission agreements with third countries. Regardless of these provisions, member-states have the power to decide on the scale of admission of third-country nationals onto their territory in search of work, whether employed or self-employed.

The growing importance of migration issues on the EU's political agenda was reflected in the gradual development of EU secondary law (directives, regulations etc.) in recent decades. Many strategic EU acts of law have been adopted since the early 2000s and several have already been revised or subject to proposals for replacement or recasting. They concern the entire spectrum of matters, including EU border management, regular migration, irregular (illegal) migration and human trafficking, forced migration and asylum. However, it was the 1985 Schengen Agreement with its 1990 Implementation Convention that had a symbolic meaning, providing the basis for a common area without internal borders and which - step by step - was joined by new countries.

Particular attention can be paid to legal instruments concerning regular immigration that reflect the EU approach, which assumes the adoption of sectoral legislation, by category of migrant, to finally achieve a comprehensive policy package. In this regard, the vast majority of legal acts in force deal with labour migration into the EU and establish the conditions of entry and residence of third-country nationals with high qualifications; those interested in seasonal work; those in the framework of an intra-corporate transfer; those pursuing research, studies, training, voluntary service, pupil exchange schemes or educational projects; and au pair placements. This is supplemented by the rules of a common, simplified procedure for third-country nationals applying for a residence and work permit in an EU member-state. The EU also regulates the conditions for the exercise of the right to family reunification by third-country nationals residing lawfully in the territory of the member-states - including persons granted refugee status and third-country nationals who are long-term residents - and the conditions for the exercise of the right of citizens of the Union and their family members to move and reside freely within the territory of the member-states.

The 2010s saw a significant change in the migration and asylum situation in Europe due to the increase in the inflow of forced and irregular migrants from the Middle East and Africa. The years 2015-2016 were considered the peak of the so-called migration and refugee crisis, with one million crossing the Mediterranean Sea to Europe in 2015 (UNCHR 2018), 1.8 million detected cases of illegal crossings between border-crossing points at the EU's external border in 2015 (European Border and Coast Guard Agency - Frontex 2018) and a very 
high number of asylum applications submitted by third-country nationals in the EU-28 - that is, 1.3 million annually in 2015-2016 (Eurostat 2018). This time, it was the European Commission's 'European Agenda on Migration', announced in May 2015, which turned out to be a key strategic document in framing the EU's approach to migration in the following years. It identified emergency actions to be taken immediately in the EU and in its neighbourhood in order to face the most urgent challenges of the crisis. These were, inter alia, two-year relocation and resettlement schemes in 2015-2017 dedicated to asylum-seekers and to setting up hot spots in Italy and Greece. The Agenda also proposed several actions designed to better manage migration in the medium and long term, divided into four main pillars aimed at reducing the incentives for irregular migration, saving migrants' lives and securing the external borders, strengthening the common asylum policy and developing a new policy on legal migration. In the context of the latter, reprioritising funding for integration policies was listed among the key actions to be taken in the future. The Agenda clearly stated that

Our migration policy will succeed if underpinned by effective integration policies. Although the competence lies primarily with Member States, the European Union can support actions by national governments, local authorities and civil society engaged in the complex and long term process of fostering integration and mutual trust.

(European Commission 2015: 16)

In other words, it can be deduced that integration policies in EU member-states supported by the EU framework determine the success of EU migration policy. Returning to the solutions proposed in the Agenda, these have been gradually implemented in the EU since 2015, albeit at different speeds and with varying degrees of success. The migration and refugee crisis showed that a reform of EU policy in the area of migration, asylum and border management was necessary, making it one of the priorities of the EU's political agenda. In its progress report of March 2019, the Commission stressed that a comprehensive approach based on the joint efforts of member-states and the EU, in close cooperation with external actors, was still necessary in order to provide better management of migration in Europe (see European Commission 2019).

The regular increase in the inflow of migrants to the EU in recent decades has resulted in the need to address the issue of their admission and integration from a long-term perspective. Integration-related issues began to appear gradually in subsequent EU (political) documents focused on migration, usually regarding legal migration and third-country nationals. This list included the Tampere Programme (1999), Communication from the Commission to the Council and the European Parliament on a Community Immigration Policy (2000), Communication from the Commission to the Council, the European Parliament, the European Economic and Social Committee and the Committee of the Regions on Immigration, Integration and Employment (2003), Thessaloniki European Council Conclusions (2003), The Hague Program (2005), the European Pact on Immigration 
and Asylum (2008) and the Stockholm Programme (2009) (see Duszczyk 2011). In these documents, information on the relationship between integration and immigration - or, rather, about the importance of integration for migration policy appeared in different ways. For example, in the Thessaloniki European Council Conclusions, in the section discussing immigration, borders and asylum, it was stated that 'the issue of the smooth integration of legal migrants into EU societies should also be further examined and enhanced', while the section dedicated to integration proposed to understand integration policies as 'a continuous, two-way process based on mutual rights and corresponding obligations of legally residing third-country nationals and the host societies'. If they are successful, they could contribute to social cohesion and economic welfare. The formulation from the Stockholm Programme is also interesting, in which the European Council stated that

the long-term consequences of migration, for example on the labour markets and the social situation of migrants, have to be taken into account and that the interconnection between migration and integration remains crucial, inter alia, with regard to the fundamental values of the Union.

(European Council 2010)

To this end, the Council stressed the key importance of the successful integration of legally residing third-country nationals in order to maximise the benefits of immigration. Once again, it has been said - implicitly - that integration policy determines immigration policy and is not just its simple sub-policy or a complementary element.

In the light of today's EU's primary law, 'integration' in the context of migration is mentioned only once in the treaties, while the term 'integration policy' does not appear at all. Article 79(4) of the TFEU states that

The European Parliament and the Council, acting in accordance with the ordinary legislative procedure, may establish measures to provide incentives and support for the action of Member States with a view to promoting the integration of third-country nationals residing legally in their territories, excluding any harmonisation of the laws and regulations of the Member States.

(European Union 2016b: Article 79(4))

There are two important conclusions that flow from this provision. Firstly, 'integration', for the EU, refers only to third-country nationals - that is, to non-EU citizens - and only those who legally reside in its member-states, which would indicate that EU citizens do not need to integrate when they live in an EU country different from their country of origin. Secondly, integration is not subject to the harmonisation of national law at the EU level, which means that states conduct their own integration policies within national legal regimes in this matter and that the EU supports them only in integration efforts and provides incentives in this regard. If the EU competence in the field of integration is limited, the inclusion of 
Article 79(4) in the TFEU is an important milestone that gives EU institutions any mandate in the field of migrant integration. In this context and in light of the scope of this book on the relations between immigration and integration policies, the integration of immigrants (and, more specifically, of third-country nationals) and the corresponding policy from a legal perspective are part of a wider immigration policy at the EU level. The superiority of immigration policy over integration policy was noticeable before the Treaty of Lisbon. Strengthening the integration of third-country nationals legally living in EU countries as an essential goal for EU immigration policy was stated by the Commission of the European Communities in 2004. In practice, following the stipulations of Article 79(4) of the TFEU, EU integration activities are mostly carried out using nonbinding tools (e.g. common standards and principles or good practices such as 11 EU-wide Common Basic Principles for Immigrant Integration Policy or the European Web Site on Integration) as well as dedicated funds and programmes (such as the European Integration Fund for 2007-2013 and the Asylum, Migration and Integration Fund for 2014-2020) which the member-states can use for the purpose of the integration of third-country nationals. Geddes and Scholten (2016) perceive these measures as an expression of soft(er) governance mechanisms at EU level, while Van Wolleghem (2019) approaches the EU's policy on the integration of migrants through the prism of the concept of a soft Europeanisation that is understood as the process encompassing both bottom-up and top-down phases.

The review of EU legal and political documents shows that integration is, in general, understood as a dynamic, two-way process based on the mutual rights and corresponding obligations of legally resident third-country nationals in EU member-states and the host society. In its December 2003 opinion, the European Socio-Economic Committee confirmed that integration is a bilateral process which involves gradually bringing the scope of immigrants' rights and obligations, as well as their access to goods, services and methods of civic participation, closer to those enjoyed by the rest of the population, with regard to equal opportunities and equal treatment. Since then, this understanding of integration has been regularly mentioned in different EU documents and has become the core component of the EU approach in this regard.

An important milestone in the development of an EU integration policy was an adoption of the set of 11 Common Basic Principles for Immigrant Integration Policy in the EU in 2004 by the Justice and Home Affairs Council (JHA) (Council of the European Union 2004). They started with the general definition of integration as 'a dynamic, two-way process of mutual accommodation by all immigrants and residents of Member States', followed by the presentation of the wide spectrum of dimensions of this process (employment, education, equal and non-discriminatory access to public and private goods and services, cultural and religious diversity, participation in democratic processes and a basic knowledge of the host society's language, history and institutions) and ended with a request to monitor and evaluate integration policies using appropriate indicators. Employment - corresponding to economic integration - was recognised as a cornerstone of the integration of immigrants in a new society. Even if the principles themselves did not refer to 
the relationship between immigration and integration policies, in the introductory considerations, the Council stressed that

A critical aspect of managing migration is the successful integration of legally residing immigrants and their descendants. At the same time immigration policy can contribute to the success of integration policy.

(Council of the European Union 2004: 15)

Thus, the interdependent links between immigration and integration and their policies have been highlighted. The success of an integration policy is of key importance in ensuring well-managed migration processes. Another thing that draws attention is the fact that integration is related only to 'legal' migrants (today, referred to instead as 'regular' migrants) - in other words, those living legally in the EU.

In 2005, the Commission of the European Communities announced 'A Common Agenda for Integration - Framework for the Integration of Third-Country Nationals in the European Union'. It referred to the aforementioned Common Basic Principles, which should be seen 'as main elements of all national and EU integration policies'. Also, the need to foster a more coherent EU approach to integration was expressed. In its conclusion, the Commission stated that 'legal migration and integration are inseparable and should mutually reinforce one another', indicating their co-occurrence and close relationship (see Commission of the European Communities 2005). Another key document was the 'European Agenda for the Integration of Third-Country Nationals', adopted by the European Commission in 2011. As a new EU strategy in the field of the integration of migrants, the Agenda pointed out that integration management is a shared responsibility and should involve both immigrants and residents, through more action at the local level and with the participation of the countries of origin, with the supporting role of the Commission in the planning of integration activities (see European Commission 2011). Finally, 2016 saw the adoption of the Commission's 'Action Plan on the Integration of Third Country Nationals'. The successful integration of third-country nationals in the EU was identified as a matter of common interest to all member-states, especially because European societies are becoming more and more diverse and human mobility in the world will continue in the twenty-first century. The 2016 Action Plan offered a common policy framework to help EU member-states to develop and strengthen national integration policies for migrants from third countries, combined with the corresponding financial support. The actions planned at the EU level to support member-states in their integration efforts covered such areas as pre-departure and pre-arrival measures, education, employment and vocational training, access to basic services such as housing and health care, active participation and social inclusion, as well as tools for coordination, funding and monitoring. In this way, the Action Plan became the next stage in the evolution of the EU approach to the integration of migrants - this time, considered a holistic one. The Action Plan highlighted the need to think about integration measures at pre-departure and pre-arrival stage, that is, at the 
earliest possible moment in the migration process, which allows both migrants and receiving communities to better prepare for the former's full integration. The pre-integration measures are beneficial for anyone moving legally to the EU but are especially important for resettled refugees (see European Commission 2016).

There is no EU legislation focused on the integration of third-country nationals per se, although certain aspects of this process are regulated under the acts of law regarding immigration - that is, those on family reunification and conditions of entry, stay, residence and work in the EU. EU legislation, which indirectly affects their integration, includes acts on combating discrimination, xenophobia and racism, counteracting social exclusion and strengthening social cohesion. A separate issue is acts of law and activities directed at asylum-seekers (instead related to reception conditions during the asylum procedure) and beneficiaries of international and national protection - mostly refugees as they are a group with specific needs.

\section{Conclusions}

This chapter has examined the issue of relations between immigration (admissions) and integration policies in Europe from several angles. The first part focused on the reconstruction of postwar migration processes that had revealed specific moments when (inter)dependencies of these policies were especially evident. In the first decades after World War II, the migration flows to Western European countries were highly determined by market forces, with migrants being recognised as an interim solution to the recovery of local economies and, subsequently, to filling workforce shortages in rapidly growing industries. It was not until the economic crisis of the early 1970s and the 'zero immigration' policy proclaimed by the main destination countries in Western Europe that many governments faced the transformation of temporary guestworkers into permanent settlers and recognised the request for an integration policy. It appeared, then, to be a pivotal moment in European governments' perceptions of and political approaches towards migration. The concerns of managing the admission of immigrants and preventing their socio-economic marginalisation also became a key issue for 'new' immigration countries in Southern Europe in the 1980s and 1990s and, in subsequent decades, for Central European countries.

In the second part of this chapter, more detailed considerations were presented on selected European countries' approaches to integration. Despite the fact that states' policy responses in this domain are conditioned by various historical and institutional circumstances as well as different frames of negotiating national identity and belonging and of assuring social cohesion, the migration literature - as well as a substantial body of historical evidence of integration policies implemented in the Western hemisphere - brings to light several theoretical conceptualisations and practical references that enable the clarification of the issues being investigated. One can recognise that states' responses to the presence of immigrants stretch from models oriented towards the exclusion of specific migrant groups (where citizenship is equivalent to ethnicity), to the assimilationist 
models based on the idea of loyalty towards the nation-state (whereby an immigrant becomes a full-fledged member of society through naturalisation), to multicultural approaches that allow for cultural diversity by providing citizens of nondominant backgrounds with the right to openly manifest their cultural distinctiveness. On the other hand, as many scholars argue, despite these seemingly wide discrepancies between particular policy models, there is, in practice, significant convergence in policy solutions towards immigration. It is particularly visible at the lowest governance level (cities and local administration) and results in the transformation of policies from the historically grounded top-down (centralist) models to seemingly more applicable and efficient bottom-up policy-making or, where state authorities still tend to shape both immigration and integration policies - to the multilevel governance of migrant issues.

In this context there is also room for supranational entities, like the European Union, which operate traditionally in the sphere of migrants' admission but which have recently also developed policy solutions to facilitate their integration. The importance of migration issues and the scope of their regulation in EU law changed along with the development of European integration. The growing interest in this field was already noticeable at the turn of the 1980s and 1990s, although the key moment was the adoption of the Treaty of Lisbon, giving the EU a legal personality and ordering the EU legal system. Since then, the EU has been pursuing a policy, known as common, in the areas of borders, immigration and asylum, based on shared competence. Consequently, the EU approach to migration is firmly anchored in its legal and institutional framework. Recent years marked by the migration and refugee crisis have shown that the governments of many EU member-states are increasingly emphasising their national competence in the migration arena, especially in the field of asylum policy. The interest in immigrant integration began to increase at the EU level at the turn of the 1990s and 2000s. At that time, integration policy was treated as complementary to migration policy, whose high efficiency and achievement of migration goals would not be possible without the implementation of an effective (successful) mechanism of involving foreigners in European societies and their institutions (Duszczyk 2011). This complementary nature of integration policy has already been outlined in the first EU documents comprehensively dealing with migration, such as the Tampere Program (1999), and following EC communications and Council's conclusions (Duszczyk 2011). From the beginning of 2000, in subsequent EU documents, integration was mainly related to legal immigration and third-country nationals. At the same time, a change in the EU approach could be observed from that promoting multiculturalism to the model aimed at foreigners' full socio-economic independence (Duszczyk 2011). The Treaty of Lisbon turned out to be a breakthrough in the development of an integration policy because it formally provided the EU with the possibility of influencing integration in its member-states. From a legal point of view, as already mentioned, integration is part of the EU's immigration policy and does not constitute a separate, common policy. In such a way, as the entire immigration policy is subject to shared competence, it falls under the area of freedom, security and justice. In practice, the broadly understood integration of 
migrants remained the domain of the member-states and their national law. However, the changing migration reality of Europe and the transformation of European societies into more culturally diverse ones in recent years have increased the demand for integration initiatives at the EU level. Van Wolleghem (2019: 190) claims that EU integration policy does not exist; however, 'there is a consistent set of policy instruments that together form a policy relating to integration but talking of an EU integration policy as of yet is hardly valid'. In the same context, Geddes and Scholten (2016: 171) conclude that 'there is not an EU migrant integration paradigm and it is highly unlikely that one will emerge'. What, however, draws their attention, are various measures of a binding and nonbinding nature at the EU level which correspond to transgovernmental and multilevel dynamics. The Union is distinguished by the promotion of integration as a two-way process which concerns not only immigrants but also residents. It draws attention to the fact that rights and obligations apply to both parties in this process and common efforts are required. The weakness of the EU's approach is in limiting integration only to third-country nationals, which questions the need to integrate citizens of one EU country living in another member-state. Thus far, the lack of a common EU integration policy has resulted in a soft, gradual Europeanisation of national policies by using such incentives as good practice and dedicated funds.

\section{Note}

1 The Treaty of Lisbon amending the Treaty on the European Union and the Treaty Establishing the European Community, signed in Lisbon on 13 December 2007, OJ C 306, 17.12.2007. With this signing, the Treaty Establishing the European Community was renamed the Treaty on the Functioning of the European Union (TFEU) and the Union replaced the Community, becoming its legal successor. Since 1 December 2009, the EU has been functioning as a full international organisation (in fact, a supranational one) whose legal basis are two treaties: the Treaty on the European Union (TEU) and the aforementioned TFEU.

\section{References}

Alexander, M. (2007) Cities and Labour Immigration: Comparing Policy Responses in Amsterdam, Paris, Rome and Tel Aviv. Aldershot: Ashgate.

Bertossi, C., Duyvendak, W.G.J. and Scholten, P. (2015) 'The coproduction of national models of integration: A view from France and the Netherlands', in Scholten, P. (ed.) Research-Policy Dialogues on Migrant Integration in Europe. Dordrecht: Springer, pp. 59-76.

Borawska-Kędzierska, E. and Strąk, K. (2011) Zarządzanie Granicami, Polityka Wizowa, Azylowa i Imigracyjna. Warsaw: Instytut Wydawniczy EuroPrawo.

Brochmann, G. (1995. European Integration and Immigration from Third Countries. Oslo: Scandinavian University Press.

Brubaker, R. (1992) Citizenship and Nationhood in France and Germany. Cambridge, MA: Harvard University Press.

Caponio, T. and Borkert, M. (2010) The Local Dimension of Migration Policymaking. IMISCOE Reports. Amsterdam: Amsterdam University Press. 
Castles, S. (1995) 'How nation-states respond to immigration and ethnic diversity', New Community, 21(3): 293-308.

Castles, S., de Haas, H. and Miller, M.J. (2014) The Age of Migration: International Population Movements in the Modern World. New York: Guilford Press (5th edition).

Collison, S. (1993) Beyond Borders. West European Migration Policy Towards the 21st Century. London: Royal Institute of International Affairs.

Commission of the European Communities (2005) Communication from the Commission to the Council, the European Parliament, the European Economic and Social Committee and the Committee of the Regions - A Common Agenda for Integration - Framework for the Integration of Third-Country Nationals in the European Union, COM(2005)389 final, Brussels, 1.9.2005. Available at https:/eur-lex.europa.eu/legal-content/EN/ ALL/?uri=CELEX\%3A52005DC0389 (accessed 29 September 2019).

Council of the European Union (2004) Press Release 2618th Council Meeting Justice and Home Affairs, Brussels, 14615/04 (Presse 321), 19 November. Available at www. consilium.europa.eu/uedocs/cms_data/docs/pressdata/en/jha/82745.pdf (accessed 29 September 2019).

Doomernik, J. (1998) The Effectiveness of Integration Policies Towards Immigrants and Their Descendants in France, Germany and the Netherlands. Geneva: International Labour Organization.

Doomernik, J. and Bruquetas-Callejo, M. (2016) 'National immigration and integration policies in Europe since 1973', in Penninx, R. and Garcés-Mascareñas (eds) Integration Processes and Policies in Europe: Contexts, Levels and Actors. Dordrecht: Springer, pp. 57-76.

Duszczyk, M. (2011) Polityka Imigracyjna Unii Europejskiej oraz Swobodny Przeptyw Pracowników-Ewolucja i Teraźniejszość. Warsaw: Oficyna Wydawnicza ASPRA-JR.

Entzinger, H. and Scholten, P. (2014) 'Models of immigrant integration? Between national and local integration policies', in Martiniello, M. and Rath, J. (eds) An Introduction to Immigrant Incorporation Studies: European Perspectives. Amsterdam: Amsterdam University Press, pp. 371-390.

European Border and Coast Guard Agency - Frontex (2018) Annual Risk Analysis for 2018. Warsaw: European Border and Coast Guard Agency.

European Commission (2011) Communication from the Commission to the European Parliament, the Council, the European Economic and Social Committee and the Committee of the Regions - European Agenda for the Integration of Third-Country Nationals, COM (2011) 0455 final, Brussels, 20.07.2011. Available at https://eur-lex.europa.eu/legalcontent/EN/ALL/?uri=CELEX\%3A52011DC0455 (accessed 29 September 2019).

European Commission (2015) Communication from the Commission to the European Parliament, the Council, the European Economic and Social Committee and the Committee of the Regions - A European Agenda on Migration, COM (2015) 240 final, 13 May 2015. Available at https://eur-lex.europa.eu/legal-content/EN/TXT/?qid=14852553 62454\&uri=CELEX:52015DC0240 (accessed 29 September 2019).

European Commission (2016) Communication from the Commission to the European Parliament, the Council, the European Economic and Social Committee and the Committee of the Regions - Action Plan on the Integration of Third Country Nationals, Strasbourg, 7.6.2016, COM (2016) 377 final. Available at https://eur-lex.europa.eu/legal-content/ EN/TXT/?uri=COM:2016:0377:FIN (accessed 29 September 2019).

European Commission (2019) Communication from the Commission to the European Parliament, the European Council and the Council "Progress report on the Implementation of the European Agenda on Migration”. Brussels, 6.3.2019, COM (2019) 126 final. 
Available at https://ec.europa.eu/home-affairs/sites/homeaffairs/files/what-we-do/poli cies/european-agenda-migration/20190306_com-2019-126-report_en.pdf (accessed 29 September 2019).

European Council (2010) The Stockholm Programme - An Open and Secure Europe Serving and Protecting Citizens, OJ C 115, 4.5.2010. Available at https://eur-lex.europa.eu/ legal-content/EN/TXT/HTML/?uri=CELEX:52010XG0504(01)\&from=EN.

European Union (2016a) Treaty on European Union (Consolidated version 2016). OJ C 202, 7.6.2016. Available at https://eur-lex.europa.eu/legal-content/EN/TXT/?uri= CELEX:12016M/TXT (accessed 29 September 2019).

European Union (2016b) Treaty on the Functioning of the European Union (Consolidated version 2016). OJ C 202, 7.6.2016. Available at https://eur-lex.europa.eu/legal-content/ EN/TXT/?uri=CELEX:12016E/TXT (accessed 29 September 2019).

Eurostat (2018) Asylum and First Time Asylum Applicants by Citizenship, Age and Sex: Annual Aggregated Data (Rounded). Available at https://ec.europa.eu/eurostat/web/ products-datasets/-/tps00191 (accessed 21 September 2019).

Favell, A. (2001) Philosophies of Integration: Immigration and the Idea of Citizenship in France and Britain. Basingstoke: Palgrave Macmillan.

Geddes, A. and Scholten, P. (2016) The Politics of Migration and Immigration in Europe. London: Sage.

Gońda, M. and Klaus, W. (2018) 'Czynniki kształtujące polską politykę imigracyjną i integracyjną w opinii badaczy i praktyków', Polityka Społeczna, 11-12(536-537): $16-23$.

Hammar, T. (1992) 'Laws and policies regulating population movements: A European perspective', in Kritz, M.M., Lim, L.L. and Zlotnik, H. (eds) International Migration Systems. A Global Approach. Oxford: Clarendon Press, pp. 245-262.

Hansen, R. (2003) 'Migration to Europe since 1945: Its history and its lessons', in Spencer, S. (ed.) The Politics of Migration: Managing Opportunity, Conflict and Change. Oxford: Wiley-Blackwell, pp. 25-38.

Joppke, C. (2007) 'Beyond national models: Civic integration policies for immigrants in Western Europe', West European Politics, 30(1): 1-22.

Mahning, H. and Wimmer, A. (2000) 'Country-specific or convergent? A typology of immigrant policies in Western Europe', Journal of International Migration and Integration, 1(2): 177-204.

Moch, L.P. (1992) Moving Europeans. Migration in Western Europe Since 1650. Bloomington: Indiana University Press.

Niekielska-Sekuła, K. (2016) 'Selected aspects of Norwegian immigration policy towards children', Central and Eastern European Migration Review, 1(5): 129-144.

Okólski, M. (ed.) (2012) European Immigrations: Trends, Structures and Policy Implications. Amsterdam: Amsterdam University Press.

Penninx, R. (2007) 'Integration processes of migrants: Research findings and policy challenges', Migracijske i Etničke Teme, 1-2: 7-32.

Penninx, R. and Garcés-Mascareñas, B. (2016) 'The concept of integration as an analytical tool and as a policy concept', in Penninx, R. and Garcés-Mascareñas, B. (eds) Integration Processes and Policies in Europe: Contexts, Levels and Actors. Dordrecht: Springer, pp. 11-30.

Rudiger, A. and Spencer, S. (2003) 'Social integration of migrants and ethnic minorities: Policies to combat discrimination'. Paper delivered at the conference The Economic and Social Aspects of Migration, Brussels, 21-22 January. Available at www.oecd.org/ dataoecd/15/4/15516956.pdf. 
Scholten, P. and Penninx, R. (2016) 'The multilevel governance of migration and integration', in Penninx, R. and Garcés-Mascareñas, B. (eds) Integration Processes and Policies in Europe: Contexts, Levels and Actors. Dordrecht: Springer, pp. 91-108.

Süssmuth, R. and Weidenfeld, W. (eds) (2005) Managing Integration: The European Union's Responsibilities Towards Immigrants. Washington, DC: Migration Policy Institute.

UNHCR (2018) Operational Portal - Refugee Situations: Mediterranean Situation. Available at https://data2.unhcr.org/en/situations/mediterranean (accessed 21 September 2019).

Van Mol, C. and de Valk, H. (2016) 'Migration and immigrants in Europe: A historical and demographic perspective', in Penninx, R. and Garcés-Mascareñas, B. (eds) Integration Processes and Policies in Europe: Contexts, Levels and Actors. Dordrecht: Springer, pp. 31-55.

Van Wolleghem, P.G. (2019) The EU's Policy on the Integration of Migrants: A Case of Soft-Europeanization? Basingstoke: Palgrave Macmillan.

Weldon, S.A. (2006) 'The institutional context of tolerance for ethnic minorities: A comparative, multilevel analysis of Western Europe', American Journal of Political Science, 50(2): 331-349. 